\title{
Factors Influencing Household Production of Sorghum and Millet in Kiminini Sub-County of Trans-Nzoia County, Kenya
}

\author{
Wekesa P. Muyukani and Nzioka J. Muthama \\ Wangari Maathai Institute for Peace and Environmental Studies, University of Nairobi
}

Article history:

Received: 29 January 2019

Received in revised form: 04 February 2019

Accepted: 04 February 2019

Available Online: 04 February 2019

\section{Corresponding Author}

Wekesa P. Muyukani

Email Address: pwekesa@uonbi.ac.ke

\section{Keywords:}

Sorghum,

Millet,

Household governance,

food security

\begin{abstract}
The production of sorghum and millet has remained low, and to some extent declined in most regions of Kenya. Little documented information exists on the main causes of this decline and the effects on household income and food security in Kiminini sub-county, and Trans Nzoia County in general. This study therefore sought to identify the factors that influence household production of sorghum and millet in Kiminini Sub-county of Trans-Nzoia County. Specifically, the study examined the extent of production of sorghum and millet; the factors that influence farmers' preference for other crops; and the impact of such decline to households' food security. The study utilized a random sample of 100 farm households to collect primary data using a structured questionnaire and an interview schedule. Secondary data were collected from documented information on sorghum and millet production in the study area and the whole country at large. Data were then analyzed using both descriptive and inferential statistics. Data presented in this study reveal the following: First, production of sorghum and millet in Kiminini Location is low and declining. Second, socio-economic characteristics typical of most households especially food prices, education level, gender and cultural values, farm size, off-farm employment, off-farm income, total household income, farm labour supply and number of household dependents, maize preference and the negative attitude towards sorghum and millet cultivation determine sorghum and millet production in the study area. In view of the above findings, this study recommendations that there is need to increase sorghum and millet production by studying the attitudes of the producers, recognizing the important of household governance, particularly the role women play in household food production, involving them in decision-making processes, providing credit facilities and subsidizing prices of farm inputs in order to make them affordable to farmers.
\end{abstract}

\section{Introduction}

Sorghum and finger millet are important cereal crops in sub-Saharan Africa. These crops are very well adapted to the ecological conditions under which they are traditionally grown. They are the "way of life" of the people in Nigeria, and are considered the "food of the people" in Sudan where they are used in traditional dishes as is the case for many countries, and their inclusion in religious rites (Enserink, 1995; Chepng'etich et al., 2014). Their traditional role in the life of people in most countries is reflected in their traditions, and kinship patterns (Vogel and Graham, 1979).

Please cite this article as: Muyukani W. P. and N. J. Muthama (2019). Factors Influencing Household Production of Sorghum and Millet in Kiminini Sub-County of Trans-Nzoia County, Kenya. Journal of Sustainability, Environment and Peace 1(1) 25-31
Millets which include both finger millet and pearl millet mainly produced in Africa and India. In Triennium Ending (TE) 2012 from the global area and production of millets African countries contributed 61 percent of area under millets and 47 percent of production followed by India (31.2 percent of area and 42.53 percent of production). Among African countries Kenya contributed 0.5 percent of area and 0.5 percent of production of millets (Taylor, 2003; Ayalew, 2013) specifically finger millet with relatively lower yield than African and global average (Table 1).

Pearl millet (subsequently referred to as 'millet') is a crop of vital importance to millions of African families and is one of the world's most resilient crops (International Crop Research Institute for Semi - Arid Tropics, ICRISAT, 1996). According to ICRISAT (1996), millet is a crop that grows where not even weeds can survive. cereal (Ibid, 1996). 
Table 1: Area, production, and yield of millet in selected countries

\begin{tabular}{llll}
\hline Countries & $\begin{array}{l}\text { Area } \\
(\mathbf{0 0 0} \text { ha) }\end{array}$ & $\begin{array}{l}\text { Production } \\
(\mathbf{\prime} 000 t)\end{array}$ & $\begin{array}{l}\text { Yield } \\
(\mathbf{k g} / \mathbf{h a})\end{array}$ \\
\hline Ethiopia & $424(2.1)$ & $676(4.8)$ & 1594 \\
Kenya & $110(0.5)$ & $70(0.5)$ & 612 \\
Nigeria & $3680(18)$ & $3810(27)$ & 980 \\
Africa & $20520(61)$ & $14160(47)$ & 689 \\
India & $10520(31.2)$ & $12090(42.53)$ & 1150 \\
World & 33810 & 29900 & 885 \\
\hline
\end{tabular}

Source: Ayalew (2015)

In West Africa, millet is consumed primarily as a thick porridge, or tor, but it is also milled into flour to prepare bread and cakes. Millet is the most-preferred cereal grain grown in sahelian countries; Senegal, Mali, Niger, and Burkina Faso, where it is consumed in preference to sorghum (IFPRI, 2002). In northern Nigeria, millet flour is used in making a popular fried cake known as 'masa'. While sorghum is perhaps a better-known crop over most of the world, majority of inhabitants of the Sahel actually prefer to consume millet, a fact that should encourage greater investments in its improvement (ICRISAT, 1996).

Sorghum is the world's fifth most important cereal crop after maize, wheat, barley and rice (Mertin, 1982; Rosegrant and Evenson, 1993; de Vries and Toenniessen, 2001; Ayalew, 2015). Currently, however, the acreage devoted to sorghum and millet production in Kenya is low and declining, with little possibilities of the area under these crops expanding (RoK, 1997). The national average estimates also show that there exists a yield gap in sorghum and millet production between research stations in Kenya with 2000-4000 kilograms per hectare, as compared to 800900 kilograms per hectare on-farm production (RoK, 2001).

The volatility in production and low acreage under sorghum and millet in Kenya has particularly been noted in commercial maize growing areas, which cover about two-thirds of the total agricultural land in the country (RoK, 1997; Kilambya and Witwer, 2013). Trans-Nzoia County lies within this region and the competition from maize cultivation has, to a large extent, affected concentration on sorghum and millet production. Despite the increasing area under maize production, however, there has been corresponding increase in the cost of production and the decrease in maize prices in the recent years as a result of market liberalization. This has led to increase in food insecurity especially for poor farm households who depend on maize production for household consumption and income.

The area under sorghum production in Kenya has been increasing from 122,368 ha in 2005 to 173,172 ha in 2009 , but the national average yield per hectare has been decreasing from 1.2 metric tons (MTs) per hectare to $0.5 \mathrm{MTs} /$ ha over the same period (RoK, 2010). Several public efforts supplemented by those of nongovernmental organizations (NGOs) and other stakeholders like International Sorghum and Millet
(INTSORMIL) program and International Crop Research Institute for the Semi-Arid Tropics (ICRISAT) have, for instance, provided interventions for harnessing opportunities for productivity enhancement (HOPE), targeted at improving productivity and marketing of sorghum. These interventions have included breeding, distribution of improved HYSVs that are pest and disease tolerant, and promotion of resource conserving management practices. In spite of all these efforts, there has been marked variability in production from the expected potential yields and the actual yields.

Most sorghum grain in Kenya is consumed by rural households, who typically grind it into flour to make porridge, known as 'ugali'. Some sorghum grain is also processed into flour by commercial mills and sold in urban markets. In many cases, sorghum flour is used to enrich cassava flour before it is packaged and sold to consumers (Chemonics, 2010). The by-products from sorghum processing are typically used for animal feed production (Kilambya and Witwer, 2013)

Majority of the households in Kiminini Sub-county are farmers and produce food crops for both domestic and commercial use. However, low and declining production in the main food crop (maize) among poor farm households has compromised the food security situation in the study area. The decline in production and low acreage under sorghum and millet in Kenya has particularly been noted in commercial maize growing areas, which cover about two-thirds of the total agricultural land in the country (RoK, 1997). TransNzoia County lies within this region and the competition from maize cultivation has, to a large extent, affected concentration on sorghum and millet production. Despite the increasing area under maize production, there has been corresponding increase in the cost of production and the decrease in maize prices in the recent years as a result of market liberalization. This has led to increase in food insecurity especially for poor farm households who depend on maize production for household consumption and income.

\section{Materials and Methods}

At an average altitude of 1800 metres above sea level, the study area experiences a highland equatorial climate. The monthly mean temperature is 18.6 degrees Celsius. However, temperatures vary between $10-37$ degrees Celsius due to variations in altitude. The Countys' annual precipitation is $1,296.1 \mathrm{~mm}$, which is fairly well distributed throughout the year. The County experiences a bimodal rainfall pattern with long rains coming in the months of April to June, and the short rains in July to October (RoK, 1997). Thus, the County enjoys a favourable climate for both agriculture and livestock production.

The study area is located in the Upper Midland AgroEcological Zone (UMZ) which is endowed with brown red and brown clay soils derived from volcanic ash (RoK, 1997). The soils are fertile and have a high clay content, which during weathering gives rise to a continuous supply of plant nutrients. These soils support the growing of sorghum, finger millet, beans, maize, cassava, and potatoes (both sweet and Irish), citrus fruits, bananas, apples, avocados, tea, wheat, coffee and sunflower (Ibid, 1997). 
Trans-Nzoia county, and the study area in particular, have thus benefited from the volcanic lava flow, a great source of fertile volcanic soils. The county also supports the rearing of cattle and sheep.

Kiminini sub-county is generally flat with gentle undulations, rising steadily towards Mount Elgon in the Northwest, and to the foot of the Cherangani Hills in the East. River Nzoia with its tributaries Ewaso Nyiro, Rongai, Koitobos and Nogamet rivers drain part of the study area flowing into Lake Victoria.

Kiminini Sub-county has 9,372 farm households with Kiminini sub-County having 4,117 while Nabiswa subCounty has 5,255 farm households (RoK, 2001). The unit of analysis here was the household Head. Purposive sampling method was used to select the 100 households. This sample size was considered as a fair representation of the total households in the study area. Kathuri and Pals (1993), who recommended a minimum sample size of 100 , also support such a sample size for a survey research. Due to the limited research time and the vast area of Kiminini Sub-County, the sample could be attained with much ease and in a more accurate manner.

\section{Data Collection}

Primary data were obtained through conducting a field survey using a closed-ended questionnaire. Secondary data were used to complement the primary data. These included time series data on sorghum and millet production, and farm inputs. These data were obtained from statistical abstract reports, government publications such as the Trans-Nzoia County Development Plans, Population and Housing Census Reports, Ministry of Agriculture Annual Reports and Food and Agricultural Organization (FAO) publications.

\section{Data Processing and Analysis}

The Statistical Package for Social Sciences (SPSS) was used for analyzing data acquired from the field to facilitate answering the research questions. Inferential statistics (chi-square test, correlation analysis and regression analysis were run for purposes of hypotheses testing. Chi-square test (c2) is a statistical technique, which helps to establish relationships between two variables both of which are categorical in nature (Mugenda and Mugenda, 1999). The technique compares the observed frequency in each category with the expected frequency under the assumption of independence between the two variables. Both quantitative and qualitative data analyses techniques were used.

\section{Results and Discussion}

The results of the study considered education level whereby majority of the households who produce sorghum and millet in the study area have attained at least primary education. Also, majority of the households produce millet (54 percent) than sorghum (41 percent) and this indicates that majority of farm households are aware of the importance of millet as opposed to sorghum. Furthermore, the calculated $\mathrm{c} 2$ is greater than tabulated $c 2$ at $p<0.05$. This goes on to suggest that production of the two crops is to some extent influenced by the education level of the household.

Table 2. Sorghum and Millet Production by Formal Education Level

\begin{tabular}{|c|c|c|c|c|c|c|}
\hline \multirow{2}{*}{$\begin{array}{l}\text { Formal } \\
\text { Education } \\
\text { level }\end{array}$} & \multicolumn{2}{|c|}{ Sorghum } & \multirow{2}{*}{ Total } & \multicolumn{2}{|l|}{ Millet } & \multirow{2}{*}{ Total } \\
\hline & Yes & No & & Yes & No & \\
\hline $\begin{array}{l}\text { No educa- } \\
\text { tion }\end{array}$ & $\begin{array}{l}6 \\
(22.1 \\
\%)\end{array}$ & $\begin{array}{l}20 \\
(27.4 \\
\%)\end{array}$ & $\begin{array}{l}26 \\
(26.0 \\
\%)\end{array}$ & $\begin{array}{l}8 \\
(21.6 \\
\%)\end{array}$ & $\begin{array}{l}18 \\
(28.6 \\
\%)\end{array}$ & $\begin{array}{l}26 \\
(26.0 \\
\%)\end{array}$ \\
\hline Primary & $\begin{array}{l}11 \\
(40.7 \\
\%)\end{array}$ & $\begin{array}{l}29 \\
(39.7 \\
\%)\end{array}$ & $\begin{array}{l}40 \\
(40.0 \\
\%)\end{array}$ & $\begin{array}{l}20 \\
(54.0 \\
\%)\end{array}$ & $\begin{array}{l}20 \\
(31.7 \\
\%)\end{array}$ & $\begin{array}{l}40 \\
(40.0 \\
\%)\end{array}$ \\
\hline Secondary & $\begin{array}{l}10 \\
(37.0 \\
\%)\end{array}$ & $\begin{array}{l}24 \\
(22.1 \\
\%)\end{array}$ & $\begin{array}{l}34 \\
(34.0 \\
\%)\end{array}$ & $\begin{array}{l}9 \\
(24.3 \\
\%)\end{array}$ & $\begin{array}{l}25 \\
(39.7 \\
\%)\end{array}$ & $\begin{array}{l}34 \\
(34.0 \\
\%)\end{array}$ \\
\hline Total & $\begin{array}{l}27 \\
(100 \\
\%)\end{array}$ & $\begin{array}{l}73 \\
(100 \\
\%)\end{array}$ & $\begin{array}{l}100 \\
(100.0 \\
\%)\end{array}$ & $\begin{array}{l}37 \\
(100.0 \\
\%)\end{array}$ & $\begin{array}{l}63 \\
(100.0 \\
\%)\end{array}$ & $\begin{array}{l}100 \\
(100.0 \\
\%)\end{array}$ \\
\hline \multicolumn{2}{|c|}{ Cal. $\mathrm{c}^{2}=11.477$} & $\mathrm{p}=0.00$ & & \multicolumn{2}{|c|}{ Cal. $c^{2}=12.519$} & $\begin{array}{l}\mathrm{p}= \\
0.014\end{array}$ \\
\hline
\end{tabular}

Where $\mathrm{c} 2$ refers to tabulated chi square, $\mathrm{df}$ is 2 and $\mathrm{N}$ refers to the sample size.

Source: Field Survey data, 2003.

It can be noted that 87.5 and 75 percent of the sample respondents who were single women produced sorghum and millet, respectively. Single women were involved in cultivation of sorghum and millet because their decisions to grow or not to grow the two crops were never influenced by anybody. Being the de facto heads of their households, they were the sole planners and implementers of their small farms without what the respondents referred to as 'interference' from other people mostly in the cases of married households. On the other hand, only 29.4 and 47.1 percent of polygamous households produced sorghum and millet respectively. This basically implies that gender has a great influence on sorghum and millet production. The male or female influence affects the decision on whether to produce sorghum and/or millet.

Table 3. Marital Status of the Sample Respondents

\begin{tabular}{lllllll}
\hline \multirow{2}{*}{$\begin{array}{l}\text { Marital } \\
\text { Status }\end{array}$} & \multicolumn{2}{l}{ Sorghum } & \multicolumn{3}{l}{ Millet } & \multirow{2}{*}{ Total } \\
\cline { 2 - 3 } \cline { 5 - 6 } & Yes & No & & Yes & No & \\
Monog- & 10 & 48 & & 43 & 15 & \\
amous & $17.2 \%$ & $82.8 \%$ & 58 & $74.1 \%$ & $25.9 \%$ & 58 \\
Polyga- & 10 & 24 & & 16 & 18 & \\
mous & $29.4 \%$ & $70.6 \%$ & 34 & $47.1 \%$ & $52.9 \%$ & 34 \\
Single & 7 & 1 & & 6 & 2 & \\
& $87.5 \%$ & $12.5 \%$ & 8 & $75 \%$ & $25 \%$ & 8 \\
\hline
\end{tabular}

Source: Survey Data, $2003 . \quad N=100$

It is observed that the sample population has diverse occupations. Majority (88 percent) of the household heads were engaged in farming activities and the remaining 12 percent were engaged in non-farm activities. This basically suggests that majority of the households produce food for domestic consumption even though sorghum and millet production remains low in the study area. This implies that there are other salient factors that affect sorghum and millet production besides the respondents' major occupation. 
It was noted that only 12 percent of the sample respondents participated in off-farm activities. Such offfarm activities included business, working for the civil service, among others. The small percentage of household dependants on non-farm activities can be attributed to the fact that majority of the household heads were women (on de facto basis) who are left by their spouses to take care of farm production. This suggests that the sample population relies more on farm activities for their livelihoods and this is expected to be a major boost for sorghum and millet production. Sorghum and millet crops have all along been considered as 'women crops'. Since most women are left in rural areas by their spouses and sorghum and millet are 'women crops', it is expected that they will have a stronger influence on the cultivation of these crops. This explains why the production of the two crops is expected to be improve and not decline as is the case currently.

The results indicate that 88 percent of the respondents do not earn any off-farm income, while 12 percent earned some income annually. Out of the 12 percent, majority (11 percent) of the household respondents earned up to Ksh. 60,000 annually. This suggests that the respondents in the study area rely on agriculture as their main economic activity and source of income. This suggests that if sorghum and millet production is enhanced, more respondents in the study area will be even more financially stable since farming is their major occupation and the cost of sorghum and millet is high compared to maize.

It was observed that the most common land tenure system reported in the study area is private land ownership with registered title deeds (95 percent). Land tenure influences the type of crop to be grown. For instance, if it a leased piece of land, then short season crops would be preferred. Only 3 and 2 percent of the farm households were leased or rented, respectively. This suggests that majority of households have full control and user-rights of their farms, which is an inducement to invest more in farm management. However, land tenure system is not the only factor influencing household food production. Other factors such as farm size, population density, extension services and variations in ecological potential play a major role in determining the type and amount of food production.

It was noted that majority (75 percent) of the sample households have farm sizes of 5 hectares of land or less. Only 6 percent of the sample farmers own land ranging in size between 6 hectares and 20 hectares. The rest, $(19$ percent) have farms ranging in size from 21 hectares or more. Most farm households in the study area have small portions of land. Despite this fact, they remain the main producers of sorghum and millet. It was observed that all sample households in the study area grow maize. Beans follow closely in importance with 89 percent of the households cultivating the crop, 51 percent cultivate sweet potatoes, 37 percent millet while 27 percent of the households produce sorghum on subsistence scale. This implies that most of the farmers in the study area grow different crops on their farms.
Table 4. Correlates of Farm Size under Sorghum Production.

\begin{tabular}{lc}
\hline Socio-economic variable & $\begin{array}{c}\text { Pearson's } \\
\text { correlation } \\
\text { coefficient } \\
\text { (r) }\end{array}$ \\
\hline Price of Maize & $-520^{* *}$ \\
Maize Preference & $-.310^{* *}$ \\
Education & $.183^{*}$ \\
Price of Sorghum & .091 \\
Number of Household dependants & .095 \\
Household Income & .114 \\
Attitude towards sorghum & .181 \\
Taste for maize flour & -.017 \\
Agricultural extension services & -.065 \\
Farm Labour & -.138 \\
\hline **Correlation significant at 0.01 level ( 2 tailed) N=100. \\
*Correlation significant at 0.05 level (2 tailed) \\
Dependent variable - sorghum production. \\
Source: Field Survey Data, 2003.
\end{tabular}

It is observed that, only three socio-economic variables showed significant correlation with farm size. They are in the order of magnitude of $r$ : price of maize, maize preference and education. The other variables in the equation/model did not show significant relationships despite their influence. It can thus be observed that the price of maize, its preference as well as education level of the respondents has a great influence on sorghum production. This is because an increase in the prices of maize and its preference is likely to increase the level of resource investment into maize production with the likelihood of reducing the production of sorghum and millet. On the other hand, an increase in the respondents' level of education is likely to expose farmers to new agricultural technologies and increase the possibilities of high income through employment thus leading to high sorghum production. Low maize prices are likely to induce farmers to diversify their agricultural production and increases sorghum production. This explains the negative correlation with sorghum $(r=-.520, p<0.01)$.

Table 5. Correlates of Farm Size under Millet Production

\begin{tabular}{lc}
\hline Socio-economic variable & $\begin{array}{c}\text { Pearson's } \\
\text { correlation } \\
\text { coefficient } \\
\text { (r) }\end{array}$ \\
\hline Education & $.211^{*}$ \\
Farm Labour & $-.197^{*}$ \\
Maize Preference & $.316^{* *}$ \\
Price of maize & $-.562^{* *}$ \\
Taste of maize flour & .001 \\
No. of household dependants & .102 \\
Total household Income & .143 \\
Price of Millet & .153 \\
Agricultural Extension services & -.051 \\
& \\
* Correlation Significant at 0.05 level (2 tailed) & $\mathrm{N}=100$ \\
**Correlation significant at 0.01 level (2 tailed) \\
Dependent variable - millet production. \\
Source: Field Survey Data, 2003.
\end{tabular}


The above table, which involves correlates of farm size under millet production, indicates that an increase in the education level of the respondents is likely to increase the production of millet. This is because farmers are made aware of the value of sorghum and millet, new farming techniques and the need to seek extension services. On the other hand, the reduction of farm labour involved in the production of millet, reduced preference for maize and its prices will in turn increase millet production. The value attached on sorghum and millet crops will in turn reduce the preference for other crops and thus increase sorghum and millet production.

Majority of the household heads ( 80 percent) are aged between $21-60$ years, 22 percent are between $21-40$ years of age, while 58 percent are between $41-60$. Only 20 percent of the sample respondents are above 60 years of age. Respondents aged between 41 and 60 years of age did most of the sorghum and millet production in the study area. Only one female respondent above the age of 60 years produced sorghum and millet. This implies that age influences the production of sorghum and millet. As for gender, 87 percent were males while 13 percent were females. All the 13 female respondents interviewed produced sorghum and millet as opposed to 37 out of the 87 interviewed male respondents. Since most households were male-dominated and the two crops were said to be 'women crops, their production was declining because of the gender issues. Women featured less in decisionmaking and thus could not influence the expansion of the acreage under sorghum and millet. This implies that gender has got a great influence on sorghum and millet production.

Among the 27 sample households who produced sorghum, 67 percent owned 5 ha and less of land, 18 percent owned between 6-10 ha of land and 15 percent owned 21 ha and more of land. Among the 73 sample households who did not produce sorghum, 78 percent owned 5 ha and less of land, 1 percent owned between 6 -10 ha, 8 percent owned between $11-15$ ha, 10 percent owned between 16-20 ha and 3 percent owned 21 ha and more of land. Even among households owning the same farm size, some produced sorghum while others did not. Furthermore, the calculated $\mathrm{c} 2$ is greater than the tabulated $\mathrm{c} 2$ at $\mathrm{p}<0.05$. This suggests that majority of the households prefer producing maize and other crops than they do sorghum. If such a trend in production goes on, there is a likelihood of sorghum being phased out of the farming system among most farming households in the study area. A large amount of sorghum that is produced in the study area is also carried out on small-scale farms. The market price of sorghum compared to maize is very high and the cost of production for sorghum is low compared to that of maize. This implies that if large-scale farmers were involved in sorghum production, that is, if sorghum production was commercialized in the study area, then the current production trend could not be declining.

Among the 37 sample households who produced millet, 76 percent owned 5 ha and less of land, 5 percent owned between 6-10 ha of land and 4 percent owned 21 ha and more of land. Among the 63 sample households who did not produce millet, 75 percent owned 5 ha and less of land, 2 percent owned between 6-10 ha, 10 percent owned between 11-15 ha, 11 percent owned between 16-20 ha and 3 percent owned 21 ha and more of land. Even among households who own the same farm size, some produced millet while others did not.

A very small percentage ( 2 percent for sorghum and 1 percent for millet) of the crops are produced for sale. On the other hand, 45 percent of sorghum produced is consumed domestically. Like sorghum, 43 percent of millet produced is consumed domestically. The price for the crops is hard to determine since most of it is consumed locally at the household level. This implies that, the current prices of sorghum and millet could be higher if the two crops were to be produced for commercial purposes.

Whereas about 60 percent of the sample households produce sorghum and millet, production is quite low less than one $90 \mathrm{~kg}$ bag per hectare. Only a small number (20 percent) realize between $1-1090 \mathrm{~kg}$ bags per hectare of sorghum and millet, while 19 percent realize between 11 and $2090 \mathrm{~kg}$ bags per hectare of sorghum and millet. The ideal production level for sorghum and millet is estimated between 30 to $4090 \mathrm{~kg}$ bags per hectare (Limon et al, 1998). According to information obtained from the Agricultural Extension Officers, majority of the sample respondents indicated that they were willing to improve sorghum and millet production. Only 7 percent were unwilling to do so. This implies that sorghum and millet production can be improved in the study area and Kenya in general only if farmers are given the right advice, improved seeds and incentives, such as loans to cultivate the crops.

A large majority of sample respondents (96 percent) viewed sorghum and millet as being useful both as human food as well as animal feed. This means that most farmers practice intercropping of the two crops (Table 6).

Table 6. Sorghum and Millet Consumption Levels

\begin{tabular}{lll}
\hline $\begin{array}{l}\text { Consumption } \\
\text { levels }\end{array}$ & Frequency & Percent \\
\hline High & 36 & 36.0 \\
Same & 45 & 45.0 \\
Low & 19 & 19.0 \\
Total & 100 & 100.0 \\
\hline
\end{tabular}

Source: Survey Data, 2003.

$$
N=100
$$

Decision making process at the household level concerning the kind of crop to be grown and where, is influenced by age and gender of the household head. The core idea behind the concept of household governance is that interdependent actors will 'govern' their ongoing transactions in two ways. Firstly, they will use agreements concerning desired household activities. Secondly, in order to reinforce these agreements and to avoid open conflict, household members will engage in conflict-handling strategies. Household governance is thus an important factor in the production of sorghum and millet since household heads are the ones to decide which crop to grow. Table 4.2 shows the distribution of age as observed in the sample population. 
Table 7. Age of the sample respondents

\begin{tabular}{lll}
\hline Age (years) & Frequency & Percent \\
\hline $21-40$ & 22 & 22.0 \\
$41-60$ & 58 & 58.0 \\
$61-80$ & 20 & 20.0 \\
Total & 100 & 100.0 \\
\hline
\end{tabular}

Source: Survey Data, 2003.

Majority of the household heads ( 80 percent) are aged between $21-60$ years, 22 percent are between $21-40$ years of age, while 58 percent are between $41-60$. Only 20 percent of the sample respondents are above 60 years of age. Respondents aged between 41 and 60 years of age did most of the sorghum and millet production in the study area. Only one female respondent above the age of 60 years produced sorghum and millet. This implies that age influences the production of sorghum and millet. As for gender, 87 percent were males while 13 percent were females. All the 13 female respondents interviewed produced sorghum and millet as opposed to 37 out of the 87 interviewed male respondents. Since most households were male-dominated and the two crops were said to be 'women crops, their production was declining because of the gender issues. Women featured less in decisionmaking and thus could not influence the expansion of the acreage under sorghum and millet. This implies that gender has got a great influence on sorghum and millet production.

Considering gender division of labour, women are in charge of both reproductive as well as productive activities, while men focus mainly on productive activities. The main reason why sorghum and millet production is undertaken mainly by women is associated with their demand on skilful labour, which most men are unable to provide. This includes the tedious and time-consuming activities such as planting, weeding, harvesting and threshing. They do not find sufficient time because of the many other tasks they are involved in. Women should thus be closer to sorghum and millet production in order to improve their yields. In the past for instance, the main crops were sorghum and millet. The overburdening of women as well as the reduction of land size has reduced their production. Observations from the study area show that all the activities related to sorghum and millet production are undertaken by women. Indeed, these crops are referred to as women crops. All these activities combined make it difficult for women to produce or concentrate more on sorghum and Millet production.

Like women in other parts of Kenya, women in the study area are thus involved in a multiplicity of roles. This has compromised their ability and capacity to contribute to the increase in agriculture production. The production of sorghum and millet - the two crops whose production is assigned to them has similarly suffered.

\section{Conclusion and Recommendations}

Based on these findings the study makes the following conclusions: Sorghum and millet production at household level is still very low and needs to be enhanced; low production of sorghum and millet is basically influenced by socio economic factors including: level of education, household size, gender issues, dietary changes, household preference of maize products as opposed to those of sorghum and millet; lastly, the attitude towards sorghum and millet has a great influence on their production and this clearly explains why sorghum and millet production is still very low and even declining.

Food insecurity in the study area arises from the fact that farmers cannot afford either to grow or even buy maize. This can be evidenced from the fact that the sample households had low incomes and thus could not afford the prices of maize or even its production. Low income in this case was compared to the current market price of maize for a particular season. Considering Sustainable Development Goals, we should aim at eradicating extreme hunger and poverty, always seek to promote gender equality as well as empower women. Promote good health and well being and responsible production and consumption. This is a vision 2030 blueprint which in turn will help improve the production of sorghum and millet in terms of ensuring food security among poor households (USAID, 2003; World Bank, 2007).

This study has identified the factors that influence household production of sorghum and millet in Kiminini Sub-County of Trans Nzoia County, Kenya. This is important in giving a clear picture of what is needed in order to enhance the production of sorghum and millet in the study area and Kenya in general. From the research findings, it is evident that increasing the education levels of the farmers can enhance sorghum and millet production by making Agriculture education compulsory in schools. Production can also be enhanced through creating awareness among households of the importance of the two crops in terms of their nutritional value, and increasing the amount of land under sorghum and millet production by considering household governance processes. e.

Based on the findings and conclusions, this study makes the following recommendations that relate to food production policies and areas that may require future research.

Since it is evident that sorghum and millet production is low and even declining in the study area, it is important that there should be policies that aim at improving their production with consideration to the aforesaid social economic factors in mind.

Labour demands and farm input costs should be considered by the Government in order to formalize policies that will aim at subsidized farm inputs and improved farming methods in order to shoulder the burden faced by women and children in sorghum and millet production. Closer attention should be paid to the determinants of household governance in agriculture, increase pressure for greater numbers of women in agricultural organizations and decision-making positions, increase pressure for the economic, legal recognition of women's work on farms and in rural communities. This research also recommends that incentives such as loans and technical knowhow should be extended to farmers as an encouragement to improve crop production. 
This will also improve sorghum and millet production. Women should be part of the decision -making process since they are the main producers of sorghum and millet. Farmers should shun the civilization ideology and focus on production for development and not on gender and/or what is old version or rather out dated.

\section{References}

Chepng'etich E., O. Nyamwaro, E. Kiprotich Bett, and K. Kizito (2015). Factors That Influence Technical Efficiency of Sorghum Production: A Case of Small Holder Sorghum Producers in Lower Eastern Kenya Advances in Agriculture. Volume 2015, Article ID 861919, 11 pages. Hindawi Publishing Corporation, http:// dx.doi.org/10.1155/2015/861919

De Vries, J. and Toenniessen, G. (2001). Securing the harvest: Biotechnology, Breeding and Seed Systems for African Countries. CAB International, Wallingford, Oxon, UK.

Enserink, H.J. (1995). Sorghum Agronomy in West Kenya: Investigation from a Farming Systems Perspective. The Royal Tropical Institute-Amsterdam, The Netherlands.

FAO, (1989). "The State of Food and Agriculture" - 1989 - 90. Rome, Italy.

Harper, F. (1983). Principles of Arable Crop Production. Granada Publishers, London.

ICRISAT, (1996). Sorghum Production. Potancheru, Andhra Pradesh 502 324, India.

International Food Policy Research Institute- IFPRI (2002). "Achieving Sustainable

Food Security for All by 2020: Priorities and Responsibilities". IFPRI. May, 2002. Washington, DC, USA.

International Food Policy Research Institute- IFPRI, (1996). "2020 Vision - News and Views: Is There Hope for Food Plenty in Africa?". IFPRI. October, 1996. Washington, DC, USA.

Kathuri, N.J. and Pals, D.A. (1993). Introduction of Education Research. Egerton University Education Book Series.
Kenya, Republic of, (2001. Trans-Nzoia District Agriculture Annual Report. Ministry of Agriculture and Rural Development. Government Printer: Nairobi.

Kenya, Republic of, (1997), Trans-Nzoia District Development Plan 1997 -2001. Office of the Vice- President and Ministry of Planning and National Development. The Government Printer, Nairobi.

Kenya, Republic of, (2010). Economic Review of Agriculture, Ministry of Agriculture, Nairobi, Kenya.

Kilambya D., Witwer M., 2013. Analysis of incentives and disincentives for sorghum in Kenya. Technical notes series, MAFAP, FAO, Rome.

Mertin, J.V. (Ed) (1982). Sorghum in the Eighties. International Crops Research

Institute for the Semi-Arid Tropics (ICRISAT). Volume 1, Patancheru, Andhra Pradesh 502 324, India.

Mugenda, O.M. and Mugenda, A.G. (1999). Research Methods: Quantitative and Qualitative Approaches. African Centre for Technology Studies (ACTS) Press, Nairobi, Kenya.

Frontier Province of Pakistan. Journal of Agricultural Economics. 45 (1). 132-138. Norwick, UK.

Reddy, G.P., Chengappa, P.G., and Achoth, L., (1995). Marketed Surplus Response of Millet: Some Policy Implications. Andhra Pradesh, India.

Rosegrant, M.W., and Evenson, R.E. (1993). Agricultural Productivity in Pakistan And India: A Comparative analysis. International Food Policy Research Institute, Washington D.C., USA.

Taylor, J. K. N., (2003). Overview: Importance of Sorghum in Africa. In: Afripro: Workshop on the Proteins of Sorghum and Millets: Enhancing Nutritional and Function Properties for Africa. Eds. P.S. Belton and J. R. N. Taylor. Pretoria, 204 April, 2003, Paper, 01. www.africipro.org.uk.

Vogel, S. and Graham, M. (1979). (Eds). Sorghum and millet: Production and Use. IDRC Publication, Nairobi, Kenya. 